\title{
MELT DROPS MOVEMENT OVER SEMICONDUCTOR SURFACES CONTROLLED BY ELECTRIC FIELD
}

\section{УПРАВЛЯЕМОЕ ЭЛЕКТРИЧЕСКИМ ПОЛЕМ ПЕРЕМЕЩЕНИЕ КАПЕЛЬ РАСПЛАВА ПО ПОВЕРХНОСТИ ПОЛУПРОВОДНИКОВ}

\author{
SKVORTSOV, Arkadiy A. ${ }^{1 *}$; KORYACHKO, Marina V. $^{2}$; ZUEV, Sergei M. ${ }^{3}$; \\ DEMCHENKOVA, Anastasiya A. ; \\ ${ }^{1,4}$ Moscow Polytechnic University, Department of Mechanics of Materials, Moscow - Russian Federation \\ ${ }^{2}$ Moscow Polytechnic University, Department of Physics, Moscow - Russian Federation \\ ${ }^{3}$ Moscow Polytechnic University, Department of Industrial Electronics, Moscow - Russian Federation \\ ${ }^{*}$ Correspondence author \\ e-mail:skvortsovaa2009@yandex.ru
}

Received 28 October 2019; received in revised form 31 October 2019; accepted 31 October 2019

\section{RESUMO}

Os problemas de formação de zonas fundidas e sua subsequente migração sobre a superfície do material são interessantes do ponto de vista do desenvolvimento de novos métodos tecnológicos para formar estruturas microeletrônicas. Tais gotas podem ser usadas como elementos primários de trabalho de microlentes e refletores, displays e pesadores. O objetivo deste trabalho foi estudar estudos de processos de eletromigração de inclusões à base de prata e alumínio fundidas sobre superfícies de cristais semicondutores de germânio e alumínio. As questões de formação e movimento de gotas fundidas sobre as superfícies de cristais de semicondutores de silício e germânio são consideradas dentro da estrutura da abordagem eletrocapilar. É mostrado por um exemplo de sistemas Ge-Ag e Si-Al que a migração acelerada está relacionada à contribuição de um componente eletrocapilar que relaciona a força de tensão superficial de quedas de derretimento à diferença de potencial elétrico na interface. O experimento consistiu em aplicar grãos de metal na superfície das amostras e aspirar a câmara onde foram criadas pressão excessiva e temperatura da superfície. Iniciou-se a migração de inclusões por poderosos pulsos de corrente. Foi feita uma análise do efeito da corrente direta em uma gota de fundido depositada na superfície de uma matriz cristalina. Uma análise da composição das gotículas foi realizada usando o método AES, cujos resultados mostraram a relação entre as concentrações de prata e germânio. Avaliações quantitativas são dadas para taxas de migração em sistemas sob fluxo de corrente direta, bem como sob cargas de corrente pulsada. Durante o experimento, verificou-se que a energia necessária para separar a gota da matriz rígida não foi consumida. $\mathrm{O}$ valor da densidade de transferência de carga superficial foi estimado. Os resultados do trabalho podem ser utilizados para desenvolver novos métodos tecnológicos para a formação de estruturas microeletrônicas e seu uso para fins práticos.

Palavras-chave: estruturas microeletrônicas, efeito eletrocapilar, campo elétrico.

\section{ABSTRACT}

The problems of molten zones formation and their subsequent migration over material surface are of interest from the viewpoint of developing novel technological methods of forming microelectronic structures. Such drops can be used as primary working elements of microlenses and reflectors, displays, weighers. The aim of this work was experimental studying processes of electromigration of molten silver- and aluminum-based inclusions over surfaces of germanium and aluminum semiconductor crystals. The issues of formation and motion of molten drops over the surfaces of silicon and germanium semiconductor crystals are considered within the framework of the electrocapillary approach. It is shown by an example of Ge-Ag and Si-Al systems that accelerated migration is related to the contribution of an electrocapillary component that relates surface tension force of melt drops to electric potential difference at the interface. The experiment consisted in applying metal grain to the surface of the samples and vacuuming the chamber where excessive pressure and the 
surface temperature were created. Migration of inclusions by powerful current pulses was initiated. An analysis of the effect of direct current on a drop of melt deposited on the surface of a crystalline matrix was made. An analysis of the droplet composition was carried out using the AES method, the results of which showed the relationship between silver and germanium concentrations. Quantitative evaluations are given for migration rates in systems under direct current flow as well as under pulsed current loads. During the experiment, it was found that the energy required to detach the droplet from the rigid matrix was not consumed. The value of the surface charge transfer density was estimated. The results of the work can be used to develop new technological methods for the formation of microelectronic structures and their use for practical purposes.

Keywords: microelectronic structures, electrocapillary effect, electric field.

\section{АННОТАЦИЯ}

Проблемы формирования расплавленных зон и их последующей миграции по поверхности материала представляют интерес с точки зрения разработки новых технологических методов для формирования микроэлектронных структур, которые можно использовать в качестве основных рабочих элементов микролинз и отражателей, дисплеев, весов. Целью данной работы является экспериментальное изучение процессов электромиграции расплавленных включений на основе серебра и алюминия над поверхностями кристаллов полупроводника германия и алюминия. В рамках электрокапиллярного подхода рассматриваются вопросы образования и движения расплавленных капель над поверхностями полупроводниковых кристаллов кремния и германия. На примере систем Ge$\mathrm{Ag}$ и Si-Al показано, что ускоренная миграция связана со вкладом электрокапиллярного компонента, который связывает силу поверхностного натяжения капель расплава с разностью электрических потенциалов на границе раздела. Эксперимент заключался в нанесении металлического зерна на поверхность образцов и вакуумировании камеры, в которой создавалось избыточное давление и температура поверхности. Была инициирована миграция включений мощными импульсами тока. Миграция расплавленных зон контролировалась с помощью оптической микроскопии. Был проведен анализ влияния постоянного тока на каплю расплава, осажденного на поверхности кристаллической матрицы. Анализ состава капель был выполнен с использованием метода AES, результаты которого показали взаимосвязь между концентрациями серебра и германия. Были даны количественные оценки для скоростей миграции в системах при постоянном токе, а также при импульсных токовых нагрузках. В ходе эксперимента было установлено, что энергия, необходимая для отделения капли от жесткой матрицы, не расходуется. Было оценено значение плотности поверхностного переноса заряда. Результаты работы могут быть использованы для разработки новых технологических приемов формирования микроэлектронных структур и их использования в практических целях.

Ключевые слова: микроэлектронные структуры, электрокапиллярный эффект, электрическое поле.

\section{INTRODUCTION}

The problems of molten zones formation and their subsequent migration over material surface are of interest from the viewpoint of both developing novel technological methods of forming microelectronic structures (Anson et al., 1999; Mills and Su, 2006; Siewiorek et al., 2016; Lischner et al., 2016; Liu et al., 2017; Eisaabadi and Nouri, 2018) and application of such drops as primary working elements of microlenses and reflectors (Shi, 2008; Wang et al., 2011; Zohrabi et al., 2016; He et al., 2019), displays, weighers (Zhongping et al., 1995; Kang and Shin, 2001; Evtukh et al., 2003; Ahmadi et al., 2011; Heikenfeld and Steckl, 2005; Chen et al., 2014). Strong heating and melting of metal tracks deposited on semiconductor or dielectric are under operation of microelectronic devices (Cisse Haba et al., 2005; Orlov et al., 2004; Lischner et al., 2016; Skvortsov et al., 2017). Such processes start to appear at the local rise of temperature produced by high current densities $j=10^{9}$ $10^{10} \mathrm{~A} / \mathrm{m}^{2}$. The developed electric transport processes lead to damage of the metallization layer structure and directed transport of the liquid substance formed both in the volume of semiconductor plate and over its surface. The melted zones formed on the surface coagulate into drops and are expelled by the current along the lines of force of the electric field.

That is why electric field is often considered as a controlling factor of inclusions geometry at directed motion of zones under electrocapillary effect (Ahmadi et al., 2011; Ahmadi et al., 2012; Ahmadi et al., 2013; Mishra et al., 2016; Orlov and Makhmud-Akhunov, 2018; Xu et al., 2019). Indeed, when applying potential difference $\Delta \varphi$, the value of drop surface charge changes according to the Lippmann equation (Liu 
et al., 2015; Ahmadi et al., 2011; Mishra et al., 2016; Feng et al., 2016; Orlov et al., 2018) (Equation 1) where $\sigma$ is surface tension of a molten drop, $\varphi$ is electric potential and $e_{0}^{*}$ is electric charge surface density. The aim of this work was experimental investigation of electromigration of molten silver- and aluminumbased inclusions over surfaces of germanium and silicon semiconductor crystals.

\section{MATERIALS AND METHODS}

Experimental investigation of surface migration processes was performed for the $\mathrm{Ag}$ $\mathrm{Ge}$ system. The specimens were single crystalline $p$-Ge $4 \times 4 \times 15 \mathrm{~mm}^{3}$ bars with resistivity of $30 \Omega \cdot \mathrm{cm}$. A metal grain with diameter $d$ to 200 $\mu \mathrm{m}$ was put on the crystal surface, and the chamber was vacuumized to residual pressure of $\sim 50 \mathrm{~Pa}$. Then argon was filled into the chamber producing a small excess pressure. The $\mathrm{Ge}$ surface temperature was created by an external resistance heater and passing a direct electric current through the crystal. The experimental technique is stated in detail in (Skvortsov et al., 2018; Li et al., 2019).

On reaching the eutectic temperature $T_{\mathrm{e}}$, contact melting began accompanied by the appearance of a rainbow halo as a ring around the formed drop. The halo front extended for a distance (Equation 2) (where $\tau_{p}$ is time of front propagation). Appearance of a halo (observed in practically all experiments on surface migration) is related to fast surface diffusion of $\mathrm{Ag}$ and formation of the thinnest melt film at the single crystal surface. In all experiments, the melt drops moved toward the negative electrode and changed practically instantly the direction of their motion when changing the polarity of the external voltage source. In this case, only the direction of motion changed while the speed became constant. This ruled out considerable effect of temperature gradient along the specimen. Besides, no evident immersion of a drop into the matrix was observed at a surface mass transfer. This indicated an insignificant temperature difference in the radial direction that apparently was determined by the application of an external resistance heater.

An analysis of drop composition (mass transfer at $T=1123 \mathrm{~K}$ ) was made by the AES method. The specimen was put into a highvacuum $\left(10^{-7} \mathrm{~Pa}\right)$ chamber of the Auger electron spectrometer 09 IOS 10-005. Surface cleaning was made for $5 \mathrm{~min}$. with Ar ions (ion energy of
$4 \mathrm{keV}$ ). The AES results showed that the ratio $\mathrm{C}_{\mathrm{Ag}} / \mathrm{C}_{\mathrm{Ge}}$ between concentrations of silver $\left(\mathrm{C}_{\mathrm{Ag}}\right)$ and germanium $\left(\mathrm{C}_{\mathrm{Ge}}\right)$ in the area of crystallized inclusion was 0.47. The obtained ratio is somewhat low as compared with the data of the equilibrium phase diagram $\left(\mathrm{C}_{\mathrm{Ag}} / \mathrm{C}_{\mathrm{Ge}}=0.55\right)$. The observed difference is due to the process of inclusion crystallization that leads to changing the concentration ratio in favor of germanium.

\section{RESULTS AND DISCUSSION:}

The results of investigations showed that in all experiments melt drops of the $\mathrm{Ag}-\mathrm{Ge}$ system moved toward the negative electrode and reversed the direction of their motion practically instantly at the reversal of polarity of the external voltage source. In this case, only the direction of motion changed while drops velocity remained constant. This excluded appreciable influence of temperature gradient along the specimen. In this case, much attention was paid to the creation of experimental conditions preventing drops dipping into a matrix. This was achieved by minimization of temperature difference in the radial direction due to the selection of modes of an external heater and current flow through the specimen (Figure 1).

In case of drop immersion into a matrix, the motion mechanisms will be limited by the melting-crystallization processes. This will lead to an essential reduction of drop migration velocity (Schiaffino and Sonin, 1997; Yan and Fan, 2001; Gamboa et al., 2002; Gamboa et al., 2011). Besides, at such surface mass transfer, a recrystallized track will remain behind a molten inclusion. This also indicates dissolutioncrystallization processes at the front and back walls of the drop (Geguzin and Krivoglaz, 1971; Orlov and Skvortsov, 2007; Skvortsov et al., 2016a; Skvortsov et al., 2016b; Kumar et al., 2017). The specific character of surface transfer with speed $w$ is related to the occurrence of the electrocapillary effect. The essence of the supposed effect is laminar movement of liquid (in drop volume) under action of gradient of the electrostatic field according to Equation 1. In this case, $w$ has to increase as inclusion size grows; which was observed in the experiment (Figure 2).

For the Al-Si system, migration of inclusions was initiated by high-power current pulses passing through thin metal films deposited on the silicon surface. A thermal shock promoted the formation of molten zones and their migration (Sobolev and Usherenko, 2006). This was controlled with methods of optical microscopy (as 
in the $\mathrm{Ag}-\mathrm{Ge}$ system). The technique of test structures formation and experimentation is given in detail in (van Soestbergen et al., 2010; Skvortsov et al., 2016c). The main experimental results are presented in Figure 2. The results of (Orlov et al., 1989a; Orlov et al., 1989b) were used for quantitative estimation of surface charge density in the systems considered. For them, an analysis was made of direct current impact on a melt drop put on the surface of a crystalline matrix. It was shown that one of the mechanisms of surface movement of a drop may be related to a version of electrocapillary motion (Equation 3 ) where $\eta$ is melted dynamic viscosity; $E$ is electric field strength in the inclusion.

Equation 4 is mechanical force; $S_{\mathrm{k}}$ is the area of drop contact with matrix; $d$ is drop height; $a$ is drop size in the contact region. The electric field strength $E$ in the drop was estimated taking into account the effect of electric field perturbation by an inclusion (Equation 5). Equation 6 is the electric field strength in a matrix far from an inclusion; $\rho_{1}$ and $\rho_{2}$ are the resistivities of an inclusion and matrix, respectively. In these experiments $\theta=0$, so Equation 7 has to be considered in Equation 3 . Assuming that the drops are hemispherical (Equations 8, 9, 10), Equation 3 becomes Equation 11

It follows from the experimental data that the energy required to tear the drop back off the rigid matrix is not spent: $\Delta \sigma \rightarrow 0$. Thereby Equation 5 with regard to Equation 12 may be written as Equation 13. This gives linear dependence on $\ell$. The obtained relation makes it possible to quantitatively estimate the value of surface density of charge transfer from the experimental data (Figure 3). The results of the calculation are presented in Table 1.

\section{CONCLUSIONS:}

Thereby the present work contains investigation of formation and migration of $\mathrm{Ag}$ and Al-based molten zones. Carried out experiments consisted in passing a constant electric current through a crystal. Upon reaching the eutectic temperature, contact melting began, a rainbow halo in the form of a ring around the formed drop appeared, which was observed in almost all experiments on surface migration. Drops of the melt moved toward the negative electrode and changed their direction of motion when the polarity of the external voltage source changed, and when the direction changed, the speed remained constant. This phenomenon excluded a significant effect of the temperature gradient along the sample. It was also pointed out that the temperature difference in the radial direction is insignificant due to the absence of an obvious immersion of a drop in the matrix.

Migration of inclusions by powerful current pulses was initiated. An analysis of the effect of direct current on a melt drop deposited on the surface of a crystalline matrix established that one of the mechanisms of the surface motion of a drop can be associated with a variant of electrocapillary motion. During the experiment, it was found that the energy required to detach the droplet from the rigid matrix is not consumed. The value of the surface charge transfer density was also estimated. The numerical values of charge surface density for the $\mathrm{Ag}-\mathrm{Ge}$ system $\left(\mathrm{e}_{0}{ }^{*}=80 \ldots 120 \mathrm{Q} / \mathrm{m} 2\right)$ and Al-Si system $\left(\mathrm{e}_{0}{ }^{*}=776 \mathrm{Q} / \mathrm{m} 2\right)$ in the considered temperature range were obtained from an analysis of experimental data. The quantitative evaluations of migration rates in the systems at direct current flow (to $20 \mathrm{~m} / \mathrm{s}$ ) and at impulse current loads (to $30-40 \mathrm{~m} / \mathrm{s}$ ) are given.

\section{ACKNOWLEDGMENTS:}

This work was carried out as part of the RFBR project No. 18-07-00564.

\section{REFERENCES:}

1. Ahmadi, A., Buat, M.D., Hoorfar, M. Journal of Micromechanics and Microengineering, 2013, 23(4), 045001.

2. Ahmadi, A., Devlin, K.D., Hoorfar, M. Microfluidics and Nanofluidics, 2012, 12(1-4), 295-305.

3. Ahmadi, A., Holzman, J.F., Najjaran, H., Hoorfar, M. Microfluid Nanofluid, 2011, 10, 1019-1032.

4. Anson, J.P., Drew, R.A.L., Gruzleski, J.E. Metallurgical and Materials Transactions, 1999, 30B, 1027-1032.

5. Chen, L.-C., Shiu, J.-W., Cheng, W.-Y., Lo, K.-L., Chang, R.-L. 21st International Display Workshops, 2014, 2, 1162-1165.

6. Cisse Haba, T., Ablart, G., Camps, T., Olivie, F. Chaos, Solitons and Fractals, 2005, 24(2), 479-490.

7. Eisaabadi, G., Nouri, A. International Journal of Metalcasting, 2018, 12(2), 292-297.

8. Evtukh, A., Hartnagel, H., Litovchenko, V., 
Yilmazoglu, O. Materials Science and Engineering A, 2003, 353(1-2), 27-35.

9. Feng, J., Liu, B., Tian, Y., Zhang, B. 17th International Conference on Electronic Packaging Technology, China, 2016, 348351.

10. Gamboa, R.M., Brito, M.C., Serra, J.M., Alves, J.M., Vallera, A.M. Solar Energy Materials \& Solar Cells, 2002, 72, 173-181.

11. Gamboa, R.M., Brito, M.C., Serra, J.M., Maia Alves, J., Vallêra, A.M. Journal of Crystal Growth, 2011, 324(1), 26-30.

12. Geguzin, Ya.E., Krivoglaz, M.A. Motion of macroscopic inclusions in solid,. Moscow: Metallurgiya, 1971.

13. He, Z., Gou, F., Chen, R., Yin, K., Zhan, T., Wu, S.-T. Crystals, 2019, 9(6), 292.

14. Heikenfeld, J. Steckl, A.J. Applied Physics Letters, 2005, 86(1), 011105.

15. Kang, S.H., Shin, E. Solid-State Electronics, 2001, 45(2), 341-346.

16. Kumar, S., Kumar, P., Pratap, R. Journal of Physics D: Applied Physics, 2017, 50(39), $39 L T 02$.

17. Li, Y., Sun, S., Gao, Y., Yao, Y., Galstyan, E., Rudra, P., Rathi, M., Dutta, P., Pouladi, S., Ryoua, J.H., Selvamanickam, V. Journal of Applied Crystallography, 2019, 52(4), 898-902.

18. Lischner, D.J., Basseches, H., D'Altroy, F.A. ECS Journal of Solid State Science and Technology, 2016, 132(12), 2997-3001.

19. Liu, Q., Zou, R., Wu, J., Xu, K., Lu, A., Bando, Y., Golberg, D., Hu, J. Nano Letters, 2015, 15(5), 2809-2816.

20. Liu, X., Li, Y., He, Y. Physical Metallurgy and Materials Science, 2017, 48(3), 1264-1272.

21. Mills, K.C., Su, Y.C. International Materials Reviews, 2006, 51(6), 329-351.

22. Mishra, K., van den Ende, D., Mugele, F. Micromachines, 2016, 7(6), 102 . doi: 10.3390/mi7060102.

23. Orlov, A.M., Belashchenko, D.K., Oborin, L.A. Inorganic materials, 1989a, 25(2), 851854.

24. Orlov, A.M., Belashchenko, D.K., Shimansky, A.F., Oborin, L.A. Inorganic materials, 1989b, 25(3), 437-439.

25. Orlov, A.M., Makhmud-Akhunov, M.Y.,
Kuznetsova, K.V. Technical Physics, 2018, 63(11), 1576-1581.

26. Orlov, A.M., Skvortsov, A.A. Inorganic Materials, 2007, 43(5), 471-474.

27. Orlov, A.M., Skvortsov, A.A., Salanov, A.A. Semiconductors, 2004, 38(4), 376-379.

28. Schiaffino, S., Sonin, A.A. Journal of Fluid Mechanics, 1997, 343, 95-110.

29. Shi, F. Journal of Shenyang Jianzhu University (Natural Science), 2008, 24(6), 1014-1019.

30. Siewiorek, A., Sobczak, N., Sobczak, J., Kudyba, A., Kozera, R., Boczkowska, A. Journal of Materials Engineering and Performance, 2016, 25(8), 3348-3357.

31. Skvortsov, A.A., Khripach, N.A., Papkin, B.A., Pshonkin, D.E. Microelectronics International, 2018, 35(4), 197-202.

32. Skvortsov, A.A., Khripach, N.A., Zaletov, D.V., Pshonkin, D.E. Research Journal of Pharmaceutical, Biological and Chemical Sciences, 2016b, 7(6), 998-1003.

33. Skvortsov, A.A., Koryachko, M.V., Skvortsov, P.A. International Conference on Actual Problems of Electron Devices Engineering, Saratov, Russian Federation, 2016c.

34. Skvortsov, A.A., Pshonkin, D.E., Luk'yanov, M.N., Rybakova, M.R. Solid State Phenomena, 2017, 269, 31-36.

35. Skvortsov, A.A., Zuev, S.M., Koryachko, M.V., Glinskiy, V.V. Microelectronics International, 2016a, 33(2), 102-106.

36. Sobolev, V.V., Usherenko, S.M. Journal De Physique. IV:JP, 2006, 134, 977-982.

37. van Soestbergen, M., Mavinkurve, A., Rongen, R.T.H., Jansen, K.M.B., Ernst, L.J., Zhang, G.Q. Electrochimica Acta, 2010, 55(19), 5459-5469.

38. Wang, G.-W., Zheng, H.-X., Yao, S.-Y., Zhang, F.-S. Materials Science Forum, 2011, 663-665, 654-657.

39. Xu, X., Zhang, Y., Sun, L. Indian Journal of Physics, 2019, 93(4), 427-438.

40. Yan, M., Fan, Z. Journal of Materials Science, 2001, 36, 285-295.

41. Zhongping, H., Panao, Ch., Shudan, Zh., Yong, C., Baoping, W. Proceedings of the IEEE International Vacuum Microelectronics Conference, Portland, OR, USA, 1995, 1822. 
42. Zohrabi, M., Cormack, R.H., Gopinath, J.T.

Optics Express, 2016, 24(21), 23798-23809.

$$
\begin{aligned}
& \frac{\partial \sigma}{\partial \varphi}=e_{0}^{*} \\
& x \approx \sqrt{\tau_{p}} \\
& w=\frac{d}{\eta}\left(e_{0}^{*} E+\frac{F_{m}}{S_{k}}-\frac{a \Delta \sigma}{S_{k}}\right) \\
& F_{m}=2 m g \sin \theta \\
& E=\frac{3 \rho_{1}}{2 \rho_{1}+\rho_{2}} E_{0} \\
& E_{0}=j p_{2} \\
& F_{m} / S_{k}=0 \\
& d=r=\ell / 2 \\
& a=2 r \\
& S_{k}=\pi r^{2} \\
& w=\frac{1}{\eta}\left(e_{0}^{*} E r-\frac{2 \Delta \sigma}{\pi}\right) \\
& \ell=2 r \\
& w=\frac{1}{\eta} e_{0}^{*} E \frac{\ell}{2}
\end{aligned}
$$

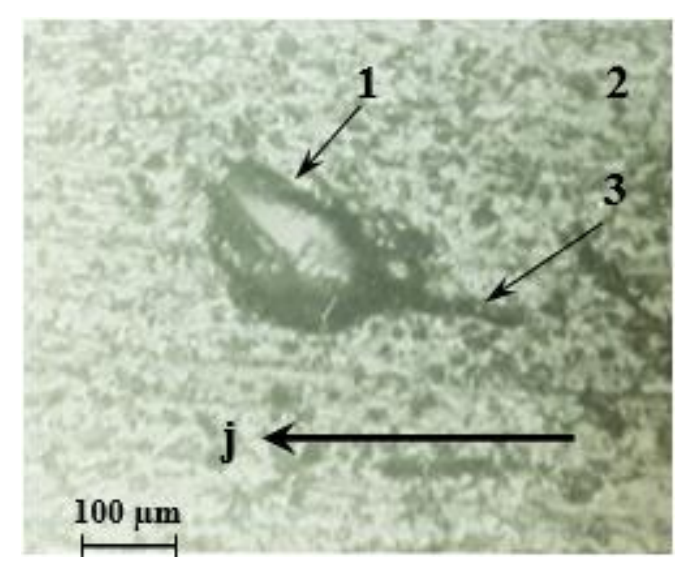

Figure 1. A photograph of moving Ag-Ge melt drop over surface of Ge single crystal: 1 - moving drop; 2-Ge surface; 3 - track (the arrow shows direction $j$ of current density vector coinciding with the drop migration direction) 


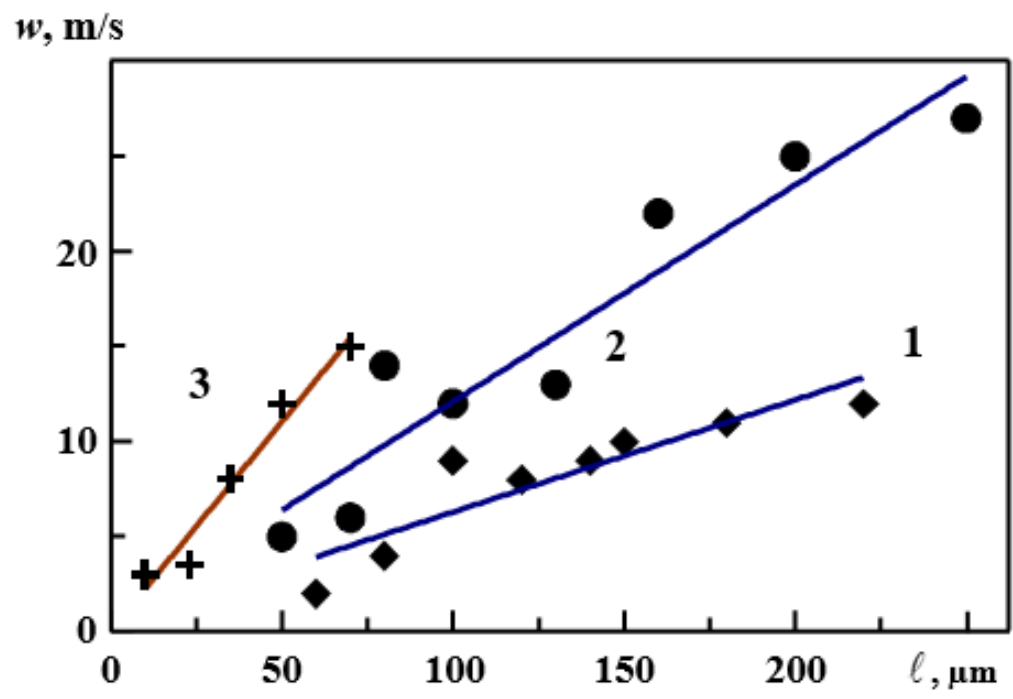

Figure 2. Dimensional dependence of surface migration velocities of melt drops: 1, 2- silver-based over Ge surface at temperatures $T=973 \mathrm{~K}$ and $1043 \mathrm{~K}$, respectively; 3 - aluminum-based over Si surface at $T=893 \mathrm{~K}$

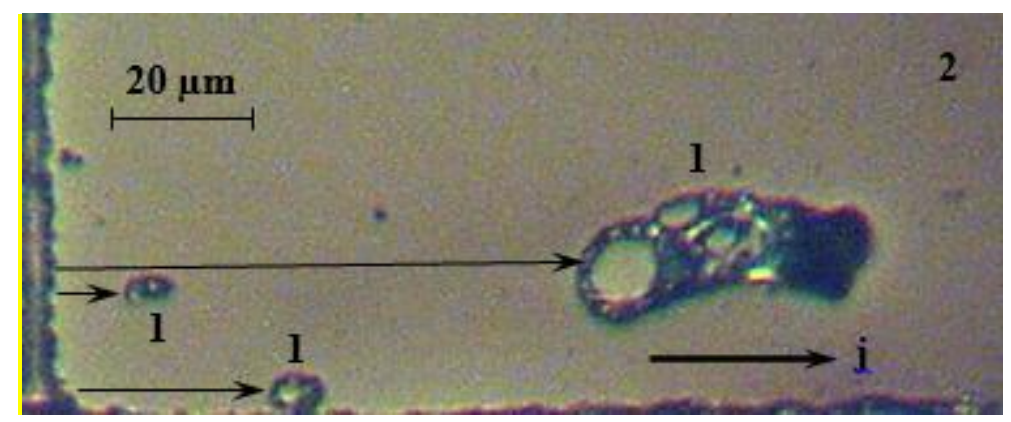

Figure 3. A photograph of electromigration processes at a silicon single crystal surface after current pulse (energy to $250 \mathrm{~mJ}$, duration of $500 \mu \mathrm{s}$ ) passing through a sprayed aluminum film: 1 - migrating melt drops; 2 - silicon surface (the arrow shows direction $j$ of current density vector coinciding with the direction of molten zones migration)

Table 1. The values of calculated and experimental data on Ag-and Al-based inclusions migration over silicon and germanium surfaces

\begin{tabular}{cccccc}
\hline \multirow{2}{*}{ № } & \multirow{2}{*}{ Parameter } & \multirow{2}{*}{ Dimensionality } & \multicolumn{3}{c}{ Temperature, $\mathbf{K}$} \\
\cline { 4 - 6 } & & - & $\mathbf{1 0 4 3}$ & $\mathbf{9 7 3}$ & $\mathbf{8 9 3}$ \\
\hline 1 & System & $1 / \mathrm{s}$ & $\mathrm{Ag}-\mathrm{Ge}$ & $\mathrm{Ag}-\mathrm{Ge}$ & $\mathrm{Al}-\mathrm{Si}$ \\
\hline 2 & $\Delta w / \Delta \ell, 10^{6}$ & $\mathrm{~Pa} \cdot \mathrm{s}$ & 1.11 & 0.06 & 0.22 \\
\hline 3 & $\eta, 10^{-3}$ & $\mathrm{~V} / \mathrm{m}$ & 3.0 & 1.9 & 3.0 \\
\hline 4 & $E$ & $\mathrm{Q} / \mathrm{m}^{2}$ & 110 & 2.7 & 1.7 \\
\hline 5 & $e_{0}^{*}$ & & & 84.4 & 776 \\
\hline
\end{tabular}

